\title{
Konvergensi Konten Audio di Media Online (Studi Kasus Podcast Detik.com)
}

\author{
Irwan Nugroho, Irwans yah \\ Magister Ilmu Komunikasi, Fakultas Ilmu Sosial dan Politik, Universitas Indonesia \\ E-mail: irwan.kayumanis@ gmail.com
}

DOI: https://doi.org/10.21107/ilkom.v15i1.9753

\begin{abstract}
ABSTRAK
Detik.com meluncurkan podcast sebagai salah satu alternatif distribusi konten pada Februari 2020 lalu. Penelitian ini bertujuan untuk mengetahui latar belakang dan tujuan Detik.com menerbitkan konten audio podcast. Selain itu untuk mengetahui proses pembuatan podcast di Detik.com dan tantangan yang menyertainya. Konsep-konsep tentang podcast dan konvergensi media digunakan sebagai alat bantu analisis. Penelitian ini merupakan penelitian kualitatif dengan paradigma interpretif. Hasil penelitian menunjukkan bahwa podcast dikembangkan Detik.com untuk memperluas variasi konten, medium distribusi konten, serta menciptakan pengalaman baru untuk para jurnalis dalam bercerita (storytelling). Podcast dipilih karena dinilai lebih fleksibel dibandingkan dengan radio. Podcast bersifat lebih timeless, dapat didengarkan kapan saja dan di mana saja. Selain itu siaran podcast tidak dibatasi oleh durasi. Podcast Detik.com ditargetkan untuk menambah jumlah pembaca muda dan membentuk engagement dengan mereka. Podcast menuntut para jurnalis Detik.com yang sebagian besar tidak mempunyai latar belakang penyiaran untuk menguasai beberapa skill dan pekerjaan sekaligus. Podcast Detik.com dibuat dengan proses yang sangat sederhana, cepat, dan tanpa biaya. Pendengar podcast Detik.com belum terlalu besar, namun konten audio tersebut telah berhasil menyasar kelompok muda. Podcast memberi pengalaman baru bagi pembaca Detik.com dalam mengonsumsi berita. Mereka tidak hanya mendapatkan informasi dalam bentuk berita teks, melainkan juga audio. Masa depan podcast serta prospek monetisasinya membuat Detik.com terus berupaya mengembangkan podcast.
\end{abstract}

Kata Kunci: podcast, konvergensi media, audio, detik.com

\begin{abstract}
Detik.com launched a podcast as an alternative content distribution in February 2020. This research was intended to determine the background and the purpose of Detik.com in publishing the podcast audio content. In addition, the aim of research was to find out the process of producing the podcast in Detik.com and the challenges faced in it. The concepts of podcast and the convergence media were used as analytical tools. The research is a qualitative research with an interpretive paradigm. The results of the research pointed out that the Podcast was developed by Detik.com to expand the content variety, the medium of distribution content, and create the new experiences for the journalist in storytelling. The Podcast has been chosen because they were considered more flexible than the radio. The Podcast of Detik.com was targeted to increase the number of young readers and shaping of engagement with them. The Podcast required the journalists of Detik.com that the most of them which do no not have broadcasting background, to master several skills and jobs at once. The Podcast of Detik.com was made in simple, fast, and chargeless. The
\end{abstract}

\section{Cite this as :}

Nugroho, Irwan \& Irwansyah (2021). Konvergensi Konten Audio di Media Online (Studi Kasus Podcast Detik.com). Jurnal Komunikasi, 15(1), 55-70. doi: https://doi.org/10.21107/ilkom.v15i1.9753

(c) 2021 Irwan Nugroho, Irwansyah

Article History:

Received January, $26^{\text {th }} 2021$ Acepted March, $02^{\text {th }} 2021$ 
listeners of Detik.com Podcast were not much yet, but the audio content has succeeded in targeting to the young people. The Podcast provides a new experience for the reader of Detik.com in consuming the news. The future of podcast and the prospect of monetization have made by The Detik.com continue its efforts to develop the podcast.

Keywords: podcast, media convergence, audio, detik.com

\section{PENDAHULUAN}

Podcast adalah sebuah fenomena dewasa ini di kalangan masyarakat perkotaan, khususnya yang berusia muda. Diawali oleh Apple Podcast pada tahun 2005, podcast makin banyak mendapatkan penggemar setelah hadir di aplikasi seperti Spotify, Google Podcast, dan lainnya. Di Amerika Serikat, sebuah survei pengguna podcast yang dilakukan Edison Research (2019) terhadap 5.626 responden berusia di atas 12 tahun menyebutkan bahwa $70 \%$ responden familiar dengan podcast. $51 \%$ responden pernah mendengarkan podcast. Mereka yang mendengarkan cerita-cerita di podcast setidaknya dalam sebulan terakhir sebelum survei sebesar 32\% dan meningkat dari tahuntahun sebelumnya. Pangsa pasar podcast meningkat $122 \%$ sejak tahun 2014 .

Di Indonesia, survei yang dilaporkan oleh DailySocial \& JakPat (2018) menunjukkan bahwa podcast makin memikat perhatian publik di tanah air. Melibatkan 2.032 pengguna smartphone sebagai responden, survei tersebut menunjukkan bahwa $68 \%$ responden akrab dengan podcast dan $81 \%$ dari mereka menikmati siaran podcast setidaknya dalam enam bulan terakhir. Sedangkan sekitar $43 \%$ mempertimbangkan untuk mengakses podcast secara teratur. Sebanyak $56 \%$ responden menilai radio dan podcast sebagai konten audio yang menarik. Namun bila dibandingkan, peminat podcast lebih tinggi $(25 \%)$ daripada radio $(18 \%)$.

Dalam survei tersebut diketahui alasan menyukai podcast antara lain karena kontennya yang lebih bervariasi (65\%), lebih fleksibel (on-demand) (62\%), serta lebih bisa dinikmati dibandingkan konten visual (38\%). Waktu yang paling disukai ketika menyimak podcast adalah setelah jam kantor. Namun, sebagian besar (79\%) lebih suka mendengarkan di rumah dengan durasi yang ideal 10-20 menit. Konten-konten yang digemari secara berurutan adalah hiburan, gaya hidup, dan teknologi. Sedangkan layanan aplikasi yang paling banyak untuk mengakses podcast adalah Spotify (52\%), SoundCloud (46\%), dan Google Podcast (41\%).

Data dari Spotify juga menunjukkan ada lebih dari 700 ribu judul podcast di platform mereka. Pengguna podcast di Indonesia terus meningkat pesat. Tahun 2020 ini, lebih dari 20 persen pengguna Spotify mendengarkan podcast setiap bulan. Jumlah waktu yang digunakan pengguna untuk mendengarkan aneka konten podcast pun meningkat sepuluh kali lipat dalam setahun terakhir. Hal itu mendorong Spotify makin masif mengkampanyekan podcast di Indonesia. Beberapa waktu lalu, mereka mengumumkan kerjasama dengan delapan podcaster (orang yang membuat podcast) papan atas di Indonesia untuk mengembangkan podcast (Kumparan, 2019).

Hadirnya podcast telah menantang eksistensi media, khususnya radio, selama beberapa tahun belakangan ini. Namun, radioradio juga membuat serial podcast yang umumnya merupakan versi lain dari siaran mereka. Tidak hanya radio, makin banyaknya pengguna podcast ternyata juga dilirik berbagai jenis media massa, baik konvensional maupun digital. Media-media non-radio menjadikan podcast sebagai salah satu alternatif distribusi konten. Dengan menggunakan lebih banyak saluran, media berharap dapat menjangkau audience lebih besar. Seperti terlihat dari pengguna podcast terbesar dari survei Daily Social-JakPat yang 
rata-rata di rentang usia 20-29 tahun, media pun membuat podcast dengan target sasaran audience berusia muda tersebut.

Sebuah laporan hasil kerjasama Reuters Institute for the Study of Journalism, Universitas Oxford, dan Flamingo tahun 2020 tentang bagaimana kaum muda mengkonsumsi berita menunjukkan, salah satu platform yang dirujuk adalah podcast. Mereka membuka konten podcast untuk mencari berita yang bersifat update terbaru. Podcast didengar oleh usia muda karena punya relevansi secara pribadi dengan mereka. Podcast adalah format yang bisa diterapkan untuk berita, karena terkait pengalaman mendalam para pendengar muda dengan suara dan topik yang jarang ditemukan di tempat lain (Reuters Institute, 2019).

Penyebaran konten melalui berbagai saluran bisa dipandang sebagai salah satu bentuk konvergensi media yang dilakukan para pelaku industri informasi. Dimensi konvergensi media tidak hanya dalam hal teknologi dan kepemilikan (konglomerasi), namun juga konten. Konvergensi media, menurut Jenkins (2006), adalah alur konten di berbagai platform media dan kerjasama antar institusi media. Konvergensi juga berarti migrasi perilaku audience yang mengakses apa saja untuk mencari jenis pengalaman hiburan yang mereka inginkan.

Reuters Digital News Report Tahun 2020 (Newman, 2020) mengungka pkan bahwa tahun 2020 bakal menjadi tahun yang besar bagi podcasting di media massa. Lebih dari setengah penerbit di dunia yang disurvei (53\%) mengatakan akan mendorong berbagai berbagai jenis inisiatif podcast pada 2020 . Sebagian melihat pengubahan artikel teks menjadi audio sebagai cara untuk memanfaatkan makin populernya format audio atau podcast saat ini.

Keberhasilan podcast Daily yang diluncurkan oleh New York Times telah memacu para publisher untuk ikut membuat podcast. Reuters mengidentifikasi ada 60 podcast berita harian di lima negara yang telah dimulai 18 bulan terakhir. Times Of London dikabarkan bakal menerbitkan podcast berita pada tahun 2020 ini. Sedangkan surat kabar Prancis, Le Monde, telah merilis tiga seri podcast baru yang diadaptasi dari serial artikel investigasi mereka.

Laporan Reuters menyebutkan,
jumlah audience yang lebih besar, pengukuran yang lebih baik, serta akses yang lebih mudah merupakan gabungan strategis untuk memonetisasi podcasting berita. Pada gilirannya ini mendorong penerbit untuk berinvestasi dalam menciptakan konten dan platform yang lebih berkualitas. Penerbit melihat podcasting sebagai kesempatan untuk menarik audience yang lebih muda, membangun kebiasaan audience, dan mendatangkan penghasilan tambahan.

Di Indonesia, sejumlah media online membuat podcast antara lain Detik.com, Kumparan.com dan Tempo.co. Melalui serial podcast, Detik.com mengajak para pendengarnya menyimak berbagai perkembangan berita yang ada di media online tersebut dengan cara yang berbeda. Sementara konten-konten podcast Kumparan.com merupakan versi audio dari berita yang sudah tersaji di situs utama mereka. Melalui Cerita Kumparan, Kumparan.com menghadirkan opini narasumber ternama, eksperimen, hingga pengalaman di balik liputan para jurnalis Kumparan.com. Tempo.co membuat podcast Apa Kata Tempo dan mengajak para pendengarnya menyimak berbagai pandangan redaksi Tempo terkait suatu isu, termasuk mengulas landasan-landasan di balik pemberitaan mereka.

Meski sudah banyak media massa yang memanfaatkan podcast sebagai salah satu distribusi konten berita, belum banyak yang tertarik untuk meneliti hal ini. Penelitian tentang Podcast di Indonesia lebih banyak dititikberatkan pada bidang pendidikan. Karena itu, penelitian ini berusaha untuk mengamati lebih dekat bagaimana konvergensi media melalui podcast ini dijalankan oleh media, khususnya media 
online. Fokus penelitian ini adalah pada media online Detik.com. Alasan pemilihan Detik.com sebagai obyek penelitian selain karena telah membuat podcast, merupakan media online pertama di Indonesia dan mempunyai jumlah pembaca terbesar hingga saat ini.

Detik.com mulai membuat serial podcast sejak Februari 2020. Podcast di Detik.com diproduksi oleh masing-masing kanal atau desk. Hingga saat ini terdapat enam program podcast yang telah diluncurkan Detik.com, yang mana empat di antaranya merupakan produksi kanal hiburan (detikHot), yaitu Ngedrakor, Gosip Pulang Kantor, dan Mainstage, dan Penonton Bayaran. Sedangkan dua program podcast lainnya diproduksi kanal berita ekonomi detikFinance (Tolak Miskin) dan teknologi detikInet (Obat Gaptek). Podcast diproduksi oleh jurnalis Detik.com yang setiap hari mengerjakan berita-berita reguler sebagai tugas utama mereka.

Podcast berita hiburan adalah siaran yang paling banyak mendatangkan pendengar, khususnya program Ngedrakor yang berisi ulasan seputar drama Korea dan berita-berita terkait dengan tema itu. Program tersebut mendatangkan 10.598 pendengar dan meraih follower tertinggi, yaitu 624 follower. Rata-rata pendengarnya pun berada di rentang usia antara 18-22 tahun dan 23-27 tahun. Untuk konten di luar hiburan, podcast Tolak Miskin juga mendapatkan atensi cukup banyak dari pendengar, yaitu sebanyak 5.116 pendengar dan 520 follower (Detikcom, 2020). Namun, konten-konten lainnya juga secara kontinue dikembangkan untuk meraih khalayak muda yang ditargetkan.

Berdasarkan hal-hal yang telah diuraikan di atas, penelitian ini bertujuan mengetahui bagaimana Detik.com menjalankan strategi konvergensi media dalam pembuatan serial podcast. Bagaimana Detik.com mengatasi persoalan sumber daya manusia berikut skill yang mereka miliki untuk menjalankan konten audio digital menjadi sesuatu yang menarik dan didengarkan oleh audience muda yang menjadi target mereka. Selain itu, seberapa besar jumlah pendengar dan respons mereka sejauh ini terhadap serial podcast Detik.com. Terakhir, bagaimana Detik.com memandang prospek bisnis siaran podcast yang dimilikinya.

\section{Podcast}

Komunikasi audio adalah bentuk komunikasi yang dilakukan melalui indera pendengaran. Jika mata hanya mampu fokus pada satu hal, maka telinga manusia bisa mendengar banyak hal sekaligus dalam satu waktu. Sebab, suara ada di mana-mana. Suara adalah kekuatan yang meliputi emosional, persepsi, dan fisik (Alten, 2014). Sementara menurut Sean Street (dalam McHugh, 2014) seorang profesor radio pertama di Inggris, pikiran manusia adalah sejenis produser atau penerima radio. Dalam arti bahwa manusia memiliki kemampuan menafsirkan perasaan yang diserap melalui suara, terutama ketika suara itu bertindak sebagai pengingat peristiwa masa lalu dalam perjalanan hidupnya.

Audio mempunyai keunggulan dibandingkan dengan video. Di antaranya audio membuat orang lebih terbuka. Orangorang bisa memilih diam ketika diletakkan kamera di depannya. Audio membebaskan pembicara dari penilaian yang bersifat fisik seperti gemuk, tua, dan jelek. Sebaliknya, pendengar dapat mengembangkan sebuah keintiman dengan pembicara ketika mereka 'menemaninya' secara realtime. Peneliti Amerika Serikat, Susan Douglas (dalam McHugh, 2014) mengatakan, tidak seperti video dan cetak yang membutuhkan perhatian penuh, audio menyertai manusia setiap waktu, baik di dalam mobil, dapur, atau melalui headphone.

Podcast adalah perkembangan dari bentuk komunikasi audio itu. Geoghegan \& Klass (2008) menjelaskan, podcasting bermula dari audioblog, sebuah aktivitas berbagai audio di website yang mulai 
berkembang pada 2001 seiring dengan hadirnya RSS Feed. Podcast sebagian besar dilihat dari evolusi blogging tersebut, yang menggunakan cara serupa untuk mendistribusikan teks ke pembaca. Podcasting adalah konten audio atau video di internet. Konten tersebut dapat dikirim ke komputer atau pemutar suara portabel. Podcasting menarik, karena siapa pun dapat terlibat, mengekspresikan diri, bertukar ide, atau melempar produk mereka.

Istilah podcast pertama muncul pada Februari 2004 ketika Ben Hammersley menulis artikel tentang audioblog dan radio online di mana ia berspekulasi tentang kemungkinan nama untuk apa yang dilakukan orang-orang tersebut. Podcasting ada di antara nama-nama itu, namun tak lama kemudian menghilang. Hingga akhirnya Dave Slusher dari "Evil Genius Chronicles" mengemukakan istilah ketika orang membuat sesuatu untuk didistribusikan melalui platform iPod sebagai "podcasting". Sejak saat itu, "podcasting" mendapatkan daya tarik dan menjadi kata yang umum digunakan.

Menurut Berry (2016) iPod, produk pemutar musik keluaran Apple, merupakan faktor kunci keberhasilan podcasting dan cara pendengar atau konsumen terlibat dengan perangkat tersebut. Michael Bull (dalam Berry, 2016) mengatakan, iPod menciptakan pengalaman mendengarkan yang dipersonalisasi atau diprivatisasi, di mana pilihan konten bersifat pribadi, tergantung pilihan para pendengar. Podcasting makin menjadi arus utama ketika Apple meluncurkan iTunes 4.9, versi pertama perangkat musik populer atau toko yang mengintegrasikan podcast langsung ke dalam perangkat lunak mereka pada tahun 2005 .

Apple mendefinisikan podcast sebagai episode program yang tersedia di internet. Selain rekaman original dalam bentuk audio ataupun video, podcast bisa juga dalam bentuk rekaman tayangan televisi, acara radio, perkuliahan, pementasan, dan sebagainya. Podcast menawarkan keuntungan bagi pendengarnya, yaitu sebuah cara untuk menikmati konten menarik dari seluruh dunia secara gratis. Sebaliknya, bagi para podcaster, layanan itu merupakan cara yang cukup efektif untuk menggapai berlipat-lipat pendengar (Apple.com, 2019).

Pertanyaan yang sering mengemuka adalah apakah podcast sama dengan radio dan apakah podcaster masuk ke dalam keluarga radio. Menurut Berry (2016b), podcasting dan radio terkait erat, namun makin terasa bahwa keduanya hidup berdampingan di jalur yang berbeda dan beririsan. Mengutip berbagai sumber penelitian, ia mengatakan podcastradio berbagi teknologi, teknik pembuatan dan penyiaran, serta berbagi konten. Meski podcast disiarkan ke banyak orang, namun beberapa hal bertentangan dengan gagasan penyiaran tradisional seperti radio. Podcast dapat berupa siaran radio, dibuat oleh stasiun radio, atau oleh mantan profesional radio. Sementara podcast lain dibuat oleh individu tanpa pengalaman siaran. Mereka juga membuat podcast dengan minat untuk terdengar seperti radio. Pendengar podcast dapat mengonsumsi dengan cara yang berbeda dengan pendengar radio tradisional.

Dalam bahasa lain, Llinares et al., (2018) mengatakan, dalam banyak hal, podcasting adalah bentuk baru. Sebab, podcast telah memfasilitasi masuknya produksi kreatif audio untuk individu dan grup tanpa latar belakang penyiaran. Stasiun radio komersial BBC di Inggris misalnya, menyuguhkan banyak sekali hambatan publik untuk masuk. Podcast juga sering menunjukkan estetika suara yang sangat berbeda di mana aturan tradisional tentang bahasa, konten, durasi dan konvensi struktural dilanggar. Asal usul dari podcast itu sendiri, menurut Llinares, adalah untuk menghindari praktik-praktik mediasi stasiun radio dan memberikan konten independen langsung kepada pendengar. Praktek podcasting bukan sekedar iterasi radio, tapi juga kumpulan karya budaya dan praktik yang mencakup jurnalisme, seni pertunjukan, komedi, drama, dokumenter, kritik, dan pendidikan.

Sementara itu, Burns (2007) mengatakan podcast memiliki empat keunggulan dibanding media komunikasi 
tradisional lainnya. Pertama, podcast memungkinkan pendengar mendengarkan konten podcast sesuai permintaan, kapan saja dan di mana saja mereka menginginkannya. Kedua, produksi untuk podcast relatif murah. Murahnya produksi podcast ini menghilangkan pengalihan biaya kepada pendengar atau dengan kata lain podcast bisa diakses gratis. Ketiga, podcast yang bersifat digital mampu membuat siapa saja di seluruh dunia mengaksesnya. Keempat, podcast sangat ramah pengguna. Salah satu alasannya adalah karena banyaknya aggregator podcast, yaitu direktori seperti iTunes, yang mengelola podcast, pencarian, dan pengunduhan podcast terbaru ke alat pemutar milik pendengar.

\section{Konvergensi Media}

Konvergensi media pertama kali dipopulerkan oleh Nicholas Negroponte pada 1979, ketika ia berceramah untuk pengumpulan dana pembangunan Media Lab di Institute Teknologi Massachusetts (MIT). Menurut Negroponte, semua teknologi komunikasi di dunia akan mengalami metamorfosis bersama-sama, yang hanya dapat dimengerti dengan baik apabila diperlakukan sebagai subjek tunggal. Untuk mengilustrasikan gagasannya tersebut, Negroponte menciptakan tiga lingkaran yang tumpang-tindih antara "industri penyiaran dan animasi bergerak", "industri komputer," dan "industri percetakan-penerbitan" (Fidler, 1997).

Negroponte dan akademisi di MIT juga diakui sebagai yang pertama mengemukakan gagasan bahwa konvergensi media dan teknologi digital pada akhirnya akan menuju pada komunikasi multimedia. Multimedia didefinisikan sebagai dua atau lebih bentuk komunikasi yang terintegrasi (Fidler, 1997). Kurang lebih sama dengan Negroponte, Burnet dan Marshall (dalam Albarran, 2013) menjelaskan konvergensi adalah perpaduan antara industri media, telekomunikasi, dan komputer, atau, dengan kata lain, pengaburan batas antara banyak platform yang berbeda dan menyatukannya menjadi satu bentuk digital.

Dwyer (2010) mengatakan konvergensi media merupakan proses di mana teknologi-teknologi baru ditampung oleh industri media, komunikasi, dan budaya yang sebelumnya sudah ada. Menurut Yicheng Zhu dalam (Grant \& Meadows, 2018), konvergensi media telah dimulai satu abad lalu ketika radio dan pemain rekaman bergabung dalam alat yang sama. Namun, konvergensi media menjadi lebih massif sejak makin menurunnya popularitas media cetak dan, sebaliknya, pesatnya pertumbuhan internet di sepanjang tahun 1990-an. Adapun Jenkins (2006) mengatakan konvergensi media terjadi ketika media lama (old media) dan media baru (new media), yang kehadirannya dipicu pertumbuhan internet tersebut, berbenturan. Internet telah mengubah secara radikal cara penyampaian informasi.

Jenkins (2006) melanjutkan, konvergensi media adalah aliran konten di berbagai jenis media. Konvergensi juga menyangkut kolaborasi beberapa institusi media. Selain itu konvergensi media berarti perilaku audience yang berubah, yakni audience mengakses apa pun untuk mencari pengalaman hiburan baru yang mereka inginkan. Ia menambahkan, konvergensi media berarti proses 3C, yaitu computing, communication, dan content. Ia juga melihat bahwa konvergensi media sebagai sebuah keberlanjutan dan seharusnya tidak dianggap sebagai perpindahan media lama ke baru, melainkan sebagai bentuk interaksi antara berbagai platform dan bentuk media.

Mendukung argumen Jenkins, M Deuze (dalam Lugmayr \& Zotto, 2016) mengatakan, konvergensi media harus dipandang sebagai kerjasama dan kolaborasi antara bentuk dan platform media yang sebelumnya tidak terhubung. Media telah terdorong untuk mengembangkan merekmerek terkemuka yang menawarkan konten dalam sejumlah bentuk dan platform yang 
berbeda. Misalnya saja, surat kabar memproduksi dan menjual buku, memasarkan radio, atau televisi streaming di bawah payung perusahaan mereka. Contoh lainnya, perusahaan film bisa saja memproduksi video game, menawarkan buku, atau membuat kartun.

Rich Gordon (dalam Quinn, 2005) lewat studinya terhadap media di Amerika Serikat mengidentifikasi konvergensi media setidaknya terjadi dalam lima bentuk. Pertama, ownership convergence, yang berlaku dalam kemitraan antara perusahaanperusahaan besar. Kemitraan itu memungkinkan terjadinya sinergi atau promosi silang berbagai konten antara media cetak dan televisi yang dimiliki perusahaan yang sama. Kedua, tactical convergence, di mana dalam pandangan ini konvergensi merupakan trik untuk kolaborasi antara media yang berbeda kepemilikan. Bisa saja sebuah surat kabar dan televisi yang tidak dalam satu kepemilikan melakukan kerjasama konten.

Ketiga, structural convergence, yang berarti pengaturan kembali ruang berita di media sekaligus memperkenalkan posisiposisi baru. Gordon memberi contoh baik tentang ini, yaitu Orlando Sentinel membentuk staf editor multimedia yang bertugas mengemas ulang materi untuk media cetak dan televisi kabel. Mendapatkan konten sebanyak mungkin juga bagian dari konvergensi struktural. Keempat, information gathering convergence. Dalam bentuk konvergensi ini, perusahaan media mengharuskan jurnalis memiliki banyak keterampilan. Misalnya, selepas dari menghadiri konferensi pers, seorang reporter menuliskan beberapa paragraf berita, membuat versi video, dan menyiapkan paket untuk televisi.

Teknologi memungkinkan bagi wartawan untuk melakukan banyak pekerjaan secara bersamaan. Namun, sebagian jurnalis ternyata tidak mempunyai keahlian teknis yang diperlukan untuk membuat banyak konten. Bahkan, pelatihan bagi jurnalis sering tidak menjadi prioritas. Bentuk kelima konvergensi adalah storytelling convergence. Setiap media baru menawarkan cara yang inovatif untuk bercerita. Bentuk-bentuk penceritaan akan muncul dalam tiga platform, yaitu dekstop, komputer, dan perangkat portabel dan televisi interaktif.

García Avilés et al., (2009) mengatakan, dari perspektif jurnalistik, konvergensi media dan integrasi ruang berita menghasilkan perubahan yang mendasar pada produksi dan pengorganisasian berita. Digitalisasi memungkinkan jurnalis untuk berbagi data baik audio, video, dan teks, untuk melebarkan konten ke berbagai platform dengan fleksibilitas yang terus meningkat. Dalam ruang redaksi yang terintegrasi, seorang jurnalis yang memiliki banyak keterampilan menghasilkan berita untuk setidaknya dua platform dari daftar berikut ini: cetak, radio, televisi perangkat seluler dan internet. Menurut Meier (dalam García Avilés et al., 2009), variasi pekerjaan yang dikuasai oleh seorang jurnalis itu mengarah pada penceritaan jurnalistik yang lebih kreatif, tapi di sini lain juga meningkatkan tuntutan atau tekanan pada para reporter atau editor.

Di Indonesia, studi mengenai konvergensi salah satunya pernah dilakukan Tapsell (2015). Menurutnya, media-media di Indonesia sedang memasuki era konvergensi yang didorong oleh teknologi media baru dan perubahan kebiasaan sehari-hari kaum muda urban. Dua perusahaan yang memelopori konvergensi itu adalah Berita Satu Holdings dan Media Group. Berita Satu Holdings milik konglomerat James Riyadi ditransformasikan dari Globe Media pada 2011 untuk lebih mencerminkan berbagai merek berita. Strategi konvergensi perusahaan itu meliputi siaran, cetak, online, dan media sosial. Sedangkan Media Group adalah grup media milik Surya Paloh. Memiliki surat kabar nasional dan daerah, juga televisi berita 24 jam, perusahaan tersebut telah sangat inovatif mempraktekkan konvergensi. Koran Media IndonZlk esia memiliki website dan e-paper. Berita-berita harian dikemas menjadi berita bulanan di iPad dan dijual melalui iTunes. 
Media-media di Indonesia juga telah membangun platform untuk jurnalisme warga sebagai bentuk keyakinan mereka memasukkan jurnalisme itu ke media arus utama. Kompas, misalnya, memiliki Kompasiana, yang sebelumnya merupakan wadah menulis untuk jurnalis mereka sendiri kemudian berkembang menjadi bersifat publik. Teтро, selain memiliki banyak platform media, juga menjalankan pelatihan untuk jurnalisme warga. Namun, UGC ini oleh para pekerja media diberlakukan penyaringan yang sangat ketat (Tapsell, 2015).

Dimensi kepemilikan dalam konvergensi media di Indonesia juga cukup cermat direkam oleh Tapsell (2015). Ia mengatakan, periode 2010-2015 merupakan periode paling produktif bagi perusahaan media di Indonesia. Tahun 2011 terjadi sejumlah merger dan akuisisi terbesar dalam sejarah industri media di Indonesia. Konvergensi telah memacu konglomerasi di Indonesia, karena perusahaan-perusahaan besar itu percaya mereka harus menjadi penyedia konten multi-platform. Bukti untuk itu adalah pembelian situs berita Detik.com seharga US\$ 70 juta oleh pengusaha Chairul Tanjung untuk dimasukkan ke dalam grup CT Corp. Selain CT Corp, Berita Satu Holdings, dan Media Group terdapat delapan konglomerasi lainnya yang menguasai bisnis media di Indonesia.

Studi Tapsell (2015) juga menyoroti dampak konvergensi terhadap praktek editorial. Semua media yang berada di dalam grup yang sama membangun sebuah platform untuk menyatukan konten mereka. Tempo, misalnya, membangun tim digital untuk menciptakan model satu ruang berita yang dapat diakses oleh semua penjaga platform. Kompas menciptakan keranjang berita di mana berita dari semua platform dipusatkan dan diintegrasikan. Jurnalis pun dituntut untuk menguasai berbagai skill jurnalistik mulai dari menulis, memotret, dan merekam audiovideo.

Untuk memperluas pasar khalayak muda melalui podcast, media-media di beberapa negara juga membuat penyesuaian di ruang redaksinya. New York Times misalnya, mempekerjakan 15 orang yang berdedikasi untuk membuat podcast berita harian "The Daily". The Guardian mempekerjakan sepuluh orang untuk program "Today in Focus". Majalah Amerika, Slate, menjadwalkan waktu beberapa jam bagi wartawannya dalam seminggu untuk rekaman podcast. Beberapa media mengalokasian sumber daya manusia lebih sedikit, menyesuaikan dengan program podcast yang hanya berisi obrolan atau wawancara mingguan dengan biaya rendah. Meski podcast menambah beban kerja, namun umumnya jurnalis antusias menyambut cara baru dalam bercerita ini (Reuters, 2019).

\section{METODE PENELITIAN}

Paradigma dalam penelitian ini adalah interpretif. Sedangkan pendekatan yang digunakan dalam penelitian ini adalah kualitatif. Paradigma interpretif dalam ilmu sosial adalah analisis sistematis mengenai aksi sosial yang bermakna melalui observasi manusia secara terperinci dan langsung dan cara mereka menjalani kehidupan sehari-hari. Paradigma ini juga bertujuan memahami makna sosial sesuai dengan konteksnya (Neuman, 2014). Sementara Creswell (2009) menyatakan pendekatan kualitatif adalah suatu bentuk inkuiri interpretif di mana peneliti membuat interpretasi tentang apa yang mereka lihat, dengar, dan pahami. Penelitian kualitatif mempunyai ciri bahwa peneliti itu sendiri merupakan instrumen kunci dalam pengumpulan data.

Metode yang digunakan dalam riset ini adalah studi kasus. Menurut R.E Stake (dalam Creswell, 2009) studi kasus merupakan strategi penyelidikan di mana peneliti mengeksplorasi secara menyeluruh sebuah program, kejadian, kegiatan, atau proses, yang dilakukan satu orang atau lebih. Penelitian ini memakai beberapa teknik penggalian data. Pertama, dengan wawancara mendalam (indepth interview). Wawancara dilakukan kepada narasumber kunci yang mengetahui 
secara detil pengembangan podcast di Detik.com. Hasil wawancara diperlakukan sebagai data primer. Detik.com menarik untuk dijadikan studi kasus, sebab merupakan media online pertama di Indonesia dan mempunyai jumlah pembaca yang besar. Selain itu, Detik.com terus melakukan inovasi untuk menjawab perkembangan teknologi media digital, termasuk podcast.

Tahap kedua, observasi, yaitu dengan cara mengamati mendengarkan, dan menganalisa program-program podcast yang dikembangan Detik.com. Ketiga, studi dokumentasi, yaitu dengan mencari naskah podcast, file audio, atau dokumentasi lain yang diperlakukan sebagai sumber sekunder dalam penelitian ini. Informan yang akan diwawancara dalam penelitian ini adalah jajaran redaksi Detik.com. Pemilihan informan disesuaikan dengan tingkatan dalam struktur keredaksian. Selain itu, informan yang diwawancara adalah produser program podcast atau awak redaksi yang dilibatkan dalam pembuatan siaran podcast.

Setelah data terkumpul, maka dilakukan analisis data kualitatif. Dalam menganalisa data yang diperoleh, digunakan koding data melalui wawancara yang telah ditranskrip dan dokumen sekunder lainnya. Koding itu dilakukan dengan tiga tahap yakni, pertama, open coding, yang berarti memeriksa data untuk meringkasnya menjadi kategori atau kode analitis awal. Kedua,axial coding, di mana peneliti menyusun kode, mengaitkan, dan menemukan kategori analitis utama. Tahap terakhir, ketiga, adalah selective coding, yaitu memeriksa kode-kode sebelumnya untuk mengidentifikasi data yang mendukung penyandian konseptual yang telah dikembangkan (Neuman, 2014). Adapun konsep-konsep yang dikoding yakni sejarah lahirnya podcast Detik.com, program podcast dan gaya penyajian, proses produksi, tuntutan multitasking jurnalis, dan pangsa pendengar podcast. Konsep tentang podcast dan konvergensi media digunakan sebagai pisau analisis untuk menjelaskan objek yang diteliti.

Teknik analisis data yang digunakan dalam penelitian ini adalah analisis naratif, di mana deskripsi atas peristiwa-peristiwa dikumpulkan dan disusun menjadi sebuah cerita dengan alur tertentu. Moleong (2019) mengatakan, narasi didefinisikan sebagai cerita atau tayangan fakta yang diceritakan kepada orang pertama. Sedangkan untuk proses konfirmasi data digunakan teknik triangulasi metode. Triangulasi adalah teknik pemeriksaan keabsahan data yang memanfaatkan sesuatu yang lain. Menurut Patton (dalam Moleong, 2019) triangulasi metode mencakup dua strategi, yaitu, pertama, pengecekan derajat kepercayaan penemuan hasil penelitian dari beberapa teknik pengumpulan data. Kedua, pengecekan derajat kepercayaan beberapa sumber data dengan metode yang sama.

\section{HASIL DAN PEMBAHASAN}

\section{Lahirnya Podcast Detik.com}

Sejak diakuisisi oleh CT Corp pada 2011, Detik.com masuk ke dalam keluarga besar Transmedia. Transmedia adalah sebuah kelompok usaha CT Corp yang bergerak di bidang media. Di dalamnya terdapat banyak media, seperti Trans TV, Trans 7, Trans Vision, CNN Indonesia, CNBC Indonesia, dan masih banyak lagi. Konvergensi media dijalankan Detik.com dengan membuat produk-produk baru sebagai distribusi konten berita. Produk-produk itu antara lain berupa majalah dan surat kabar digital. Ekosistem baru juga membuat Detik.com bekerjasama dengan media-media lainnya di bawah payung Transmedia tersebut, baik dalam hal konten, promosi konten, alat produksi, maupun sumber daya manusia (SDM).

Detik.com mulai meluncurkan serial podcast pada Februari 2020. Hingga saat ini, terdapat tiga kanal (rubrik) di Detik.com yang membuat konten podcast, yaitu kanal teknologi dan informasi (detikInet), ekonomi (detikFinance), serta hiburan (detikHot). Masing-masing kanal tersebut memiliki channel di penyedia layanan podcast seperti Spotify dan Google Podcast. Kendati demikian, seluruh episode program yang diluncurkan oleh kanal-kanal tersebut 
diunggah juga di akun podcast Detik.com sebagai akun utama perusahaan. Tercatat ada sebelas playlist yang diluncurkan oleh Detik.com pada poscast mereka di Spotify.

Ide untuk mengembangkan podcast di Detik.com sebenarnya sudah muncul sejak tahun 2016. Pada saat itu, teknologi baru tersebut sudah sangat populer di Amerika Serikat. Media-media di Amerika berlombalomba untuk membuat podcast. Selain itu, podcast diketahui sangat berpengaruh terhadap kemenangan Donald Trump dalam pemilihan Presiden Amerika pada tahun itu juga. Donald Trump menjalankan kampanye yang cukup efektif menggunakan podcast. Faktor pendorong lainnya adalah prediksi bahwa radio di Amerika dan Eropa akan berbayar dan tren tersebut cepat atau lambat akan bergeser ke Indonesia. Sebagai gantinya, podcast, yang untuk mengaksesnya tidak dikenakan biaya apapun, diperkirakan bakal makin menancapkan eksistensinya.

Sempat terdapat perbedaan pendapat antara redaksi dan divisi Product Management mengenai podcast ini. Product Management merupakan divisi yang men-develop seluruh produk Detik.com. Divisi produk memandang podcast belum banyak peminatnya di Indonesia. Selain itu, podcast tidak akan berpengaruh terhadap pertumbuhan unique visitors (UV) dan pageviews (PV) bagi Detik.com. Dengan menerbitkan podcast, pembaca dikhawatirkan justru berpindah ke aplikasi penyedia podcast dan menguntungkan pemilik layanan. Redaksi juga dinilai tidak akan dapat secara konsisten menerbitkan podcast mengingat beban pekerjaan yang sudah sangat besar. Alasan lainnya adalah perusahaan sendiri belum mempunyai peralatan untuk memproduksi podcast.

Namun, redaksi meyakini bahwa podcast dapat memunculkan engagement dengan pembaca, terutama para pembaca muda. Sebab, podcast sangat digemari di kalangan anak muda. Redaktur Pelaksana kanal berita ekonomi detikFinance, Angga Aliya ZR Firdaus (wawancara 27 Mei 2020) mengungkapkan, loyalitas pembaca muda perlu di-maintenance sejak dini, karena pembaca muda tersebut pada akhirnya bakal menua. Jika para pembaca muda ini memiliki loyalitas tinggi terhadap Detik.com, maka ujung-ujungnya adalah perolehan unique visitors dan pageviews yang tinggi juga di masa mendatang.

Redaktur Pelaksana detikHot, Nugraha Rodiana (wawancara 27 Mei 2020), mengatakan, kebutuhan untuk meningkatkan pembaca generasi milenial dan generasi $\mathrm{Z}$ juga menjadi motivasi tersendiri menerbitkan podcast hiburan. Pembaca detikHot yang tergolong dalam kedua generasi tersebut baru berkisar $20 \%$ dari total pembaca. Sementara, kalangan milenial dan Gen $\mathrm{Z}$ saat ini sudah menjadikan podcast sebagai salah satu 'habitat' mereka. Mempertimbangkan bahwa lebih baik mencoba daripada terus terlambat, ditambah pada waktu itu detikHot sedang giat menggodok produk-produk baru, maka akhirnya disepakati untuk menjajaki podcast.

Selain untuk menggaet pembaca muda, podcast juga bertujuan untuk menambah variasi konten di Detik.com. Dalan arti tidak hanya berita dalam bentuk teks. Ketika video sudah sejak lama diseriusi oleh Detik.com dengan membuat kanal 20Detik, berbeda halnya dengan konten audio. Suguhan informasi berbentuk audio dinilai dapat menjadi alternatif bagi pembaca yang jenuh dengan berita-berita teks Detik.com yang memiliki ciri khas breaking news. Terlebih untuk berita infotainment atau berita ringan yang seringkali diakses pembaca pada saat senggang atau akhir pekan.

Sebagai sesama konten audio, dibandingkan dengan radio, menurut produser podcast detikHot, Atmi Ahsani Yusron (wawancara 27 Mei 2020), podcast mempunyai beberapa keunggulan. Pertama, konten podcast lebih bersifat timeless, sehingga pendengar yang terlambat mengikuti suatu episodenya tidak perlu khawatir, karena masih bisa mengakses kapan saja mereka mau. Kedua, podcast tidak dibatasi durasi waktu, sehingga penyiar bisa mengatur durasi 
siaran sesuai dengan kebutuhan. Ketiga, podcast memungkinkan penyiarnya untuk membahas sebuah topik secara lebih luas. Keempat, pendengar bisa me-rewind siaran podcast dengan mudah bila ingin mendengarkan lagi informasi-informasi yang penting. Kelima, pendengar yang menyukai

suatu episode podcast dapat langsung membaginya kepada teman-temannya di media sosial melalui fitur berbagi.

\section{Program dan Gaya Penyajian}

Seperti telah disinggung sedikit di atas, hingga saat ini ada tiga kanal di situs berita Detik.com yang telah menciptakan konten podcast. Kanal detikInet membuat serial podcast dengan nama Obat Gaptek. Sejak bulan Februari, program Obat Gaptek telah menayangkan sebelas episode. Obat Gaptek berisi obrolan mengenai gadget, aplikasi, dan teknologi. Sebagai contoh pada edisi 6 Maret 2020 lalu, Obat Gaptek membahas tentang nasib telepon seluler yang beredar di pasar gelap sejak diterapkannya aturan IMEI. Contoh lainnya, pada 6 April 2020, Obat Gaptek membahas tentang aplikasi video conference Zoom yang banyak dipakai untuk berkomunikasi sejak pandemi COVID-19 dan menimbulkan kontroversi.

Sedangkan detikFinance mempunyai satu program podcast yang diberi nama Tolak Miskin. Angga Aliya ZR Firdaus mengatakan, isi podcast Tolak Miskin yang terbit setiap Rabu itu bukanlah berita aktual, namun lebih pada tips and trik untuk diterapkan pendengarnya dalam kehidupan sehari-hari. Tips and trik diberikan dengan lebih dulu memberi gambaran besar mengenai kondisi perekonomian. Gambaran makro ekonomi itu tetap ada sebagai narasi pembuka. Alasan konten tips dan trik itu supaya menarik dan pendengar mendapatkan sesuatu setelah mendengarkan podcast. Para pendengar telah merelakan waktu 15-30 menit untuk mendengarkan podcast, sehingga mereka perlu diberi sesuatu yang bermanfaat. Tips and trik dalam program Tolak Miskin dimaksudkan untuk membantu pembaca mengelola keuangan supaya, sesuai nama programnya, tidak jatuh miskin.

Sedangkan detikHot sampai sekarang mempunyai program podcast paling banyak, yaitu empat program dengan jadwal tayang berbeda setiap pekannya. Pertama, Ngedrakor, yang berisi ulasan tentang dramadrama Korea yang sedang tayang dan menjadi pembicaraan para penggemarnya. Kedua, Penonton Bayaran, yaitu percakapan tentang film-film yang sedang hits dari kacamata penonton yang dibayari tiketnya oleh detikHot. Ketiga, Main Stage, yaitu program podcast yang disinergikan dengan acara musik detikHot, Main Stage. Keempat, Gosip Pulang Kantor, yang berisi round up atau rangkuman peristiwa atau gosip selebritis terhangat dalam sepekan. Contoh episode program Gosip Pulang Kantor ini adalah ketika selebritis Ririn Ekawati ditangkap dalam dugaan kasus narkoba pada awal Maret 2020.

Gaya siaran podcast Detik.com sangat berbeda dengan karakter pemberitaan Detik.com yang umumnya serius dan lugas. Podcast Tolak Miskin dibawakan dengan bahasa yang lebih santai dan akrab di telinga generasi milenial dan Gen Z. Sapaan informal seperti "bro" dan "lo" bertebaran di sepanjang siaran podcast Tolak Miskin. Judul-judul episode pun dibuat dengan kata-kata yang tidak kaku atau formal jurnalistik. Contohnya judul episode No THR No Cry, yang berisi tips dan trik bagi para karyawan yang tidak mendapat Tunjangan Hari Raya pada Idul Fitri 1441 Hijriyah. Gaya bertutur seperti itu bertujuan untuk memberikan suasana rileks bagi pembaca kanal detikFinance yang isinya rata-rata cukup berat. Gaya santai juga menyesuaikan dengan karakter aplikasi podcast itu sendiri, yang memang ditujukan untuk orang-orang yang ingin bersantai dan mencari hiburan.

Sementara karena detikHot adalah kanal untuk berita-berita hiburan, maka gaya penyajian podcast sudah otomatis menyesuaikan. Pembawaan para penyiar 
selalu riang dan tidak kaku saat rekaman, tidak sebagaimana presenter radio atau televisi saat membacakan berita. Sebagai produser dan penyiar podcast Ngedrakor, Atmi Ahsani Yusron, mengatakan, obrolan dalam rekaman podcast dilakukan dengan lepas. Penyiar dan lawan bicara berbincang seperti antara teman dengan teman. Seperti dalam Ngedrakor, penyiar dan orang-orang yang terlibat dalam rekaman berbicara sebagai sesama penyuka drama Korea. Format obrolan pertemanan ini bertujuan supaya pendengar di luar sana seolah-olah merasa hadir dalam obrolan tersebut.

\section{Proses Produksi Podcast Detik.com}

Proses penggarapan podcast di Detik.com diawali terlebih dahulu dengan penentuan tema oleh jajaran redaksi. Dalam kasus podcast Tolak Miskin, penentuan tema dilakukan pada hari Senin. Setelah itu proses selanjutnya adalah pembuatan naskah atau outline tentang apa saja yang akan diobrolkan pada saat rekaman. Pembuatan naskah dilakukan secara sederhana, sehingga dapat diselesaikan dengan cepat. Rekaman dilakukan pada Selasa atau Rabu. Rekaman juga bisa selesai dengan cepat, karena apabila terdapat kesalahan cukup diulang dan dirapikan pada saat proses editing. Editing dilakukan dengan meminta bantuan tim video 20Detik. Sebelum ditayangkan, muatan podcast Tolak Miskin dievaluasi dulu pada Rabu itu juga oleh Redaktur Pelaksana. Jika dirasa sudah layak untuk disiarkan, maka produser akan mengunggah file digital-nya ke akun Spotify pada Rabu malam.

Proses pembuatan program podcast di
detikHot di bawah masing-masing
penanggungjawab program, namun
seluruhnya dikoordinasikan oleh produser.
Produser mengumpulkan informasi tentang
tema seluruh program dan kemudian
melaporkannya kepada Redaktur Pelaksana.
Rekaman setiap program mempunyai jadwal
masing-masing. Misalnya untuk Ngedrakor
yang tayang hari Rabu, rekamannya dilakukan
pada Senin. Namun, kadang-kadang

pembagian jadwal tersebut tidak berjalan seperti yang direncanakan. Rekaman program Ngedrakor seringkali baru dilakukan pada Rabu itu juga pada pukul 12.00 WIB. Hasil rekaman tersebut lantas diedit dengan cepat oleh produser. Pada pukul 15.00 WIB siaran podcast Ngedrakor sudah terbit dan bisa dinikmati oleh pendengar.

Sedangkan untuk biaya produksi podcast sangatlah murah, bahkan nol rupiah. Selain itu, tidak ada anggaran khusus yang dikeluarkan oleh perusahaan untuk membuat siaran podcast. Tidak ada pula studio yang dibangun khusus untuk rekaman podcast. Rekaman cukup hanya dilakukan di ruang rapat selama beberapa menit. Sedangkan alatalat untuk merekam dipinjam dari divisi lainnya (20Detik). Sebetulnya, redaksi detikHot ingin memiliki player sendiri untuk produksi podcast, namun belum diajukan ke perusahaan. Editing juga dilakukan sendiri oleh produser.

Setelah podcast diunggah ke aplikasi penyedia layanan, masih ada lagi tahapan lain yaitu content delivery. Agar informasi tentang terbitnya episode baru podcast sampai kepada pembaca, maka detikFinance membuat berita teks. Di dalam berita itu kemudian dilampirkan link embeded podcast di Spotify. Bagi pendengar yang mengakses menggunakan komputer dekstop, mereka dapat langsung mendengarnya dengan menekan simbol play dalam ikon Spotify yang diletakkan di bawah berita. Sedangkan yang membuka melalui smartphone akan melompat ke aplikasi Spotify saat mendengarkan podcast. Selain itu, episode podcast yang baru ini digencarkan promosinya oleh divisi media sosial. Episode podcast yang baru juga diunggah ke akun podcast Detik.com.

Lain lagi dengan sejumlah podcast yang diproduksi detikHot. Pada saat sebuah episode podcast terbit, dalam waktu yang sama juga dibuat berita dengan mencantumkan link embeded Spotify di bawah berita. Namun, setelah podcast tersebut, redaksi juga memecah kontennya ke dalam beberapa bentuk berita teks. Misalnya untuk program Ngedrakor yang tayang hari 
Rabu. Redaksi akan membuat versi berita teks pada hari Jumat. Hal itu bertujuan untuk meningkatkan keterpaparan pendengar. Sedangkan untuk program Main Stage, siaran podcast akan dipakai sebagai penutup dari program musik tersebut di akhir pekan.

\section{Tuntutan Multitasking Jurnalis}

\section{Podcast Tolak Miskin detikFinance} dijalankan oleh tiga awak redaksi. Di samping membuat podcast, mereka masih menjalankan tugasnya sehari-sehari sebagai jurnalis, yaitu meliput serta menulis berita-berita ekonomi. Mereka secara bergantian mengisi siaran podcast. Dari tiga personel tersebut, hanya satu yang mempunyai latar belakang sebagai penyiar radio, sehingga ditunjuk sebagai produser. Menurut Angga Aliya ZR Firdaus, penugasan siaran podcast tidak banyak mengganggu tugas-tugas utama para jurnalis detikFinance, begitu juga sebaliknya. Hanya saja, ketiadaan pengalaman broadcasting di sebagian besar awak redaksi menjadi kendala tersendiri. Sangat sulit untuk membiasakan sebagian awak redaksi berbicara selama beberapa menit saat rekaman. Namun, hal itu dapat diatasi dengan pelatihan informal yang dilakukan oleh produser yang berpengalaman.

Sedangkan empat podcast detikHot dijalankan oleh kurang lebih lima personel redaksi dengan satu orang sebagai produser. Meski demikian, pada prinsipnya seluruh jurnalis detikHot bisa dilibatkan dalam siaran podcast di samping meliput dan menulis berita reguler. Dari sekian orang yang terlibat podcast tersebut, hanya satu orang yang mempunyai pengalaman sebagai penyiar, yaitu Atmi Ahsani Yusron. Penunjukan sebagai produser itu dilatarbelakangi pengalamannya sebagai penyiar radio di daerah selama beberapa tahun. Ia juga direkrut khusus ketika detikHot ingin meluncurkan konten podcast.

Selain produser, satu orang lagi penanggung jawab podcast memiliki latar belakang public speaking, sehingga cukup membantu dalam podcasting. Podcast bahkan menjadi penyaluran bagi jurnalis tersebut yang sebelumnya merasa kurang greget ketika hanya bekerja sebagai jurnalis media online. Meski sudah dibagi ke beberapa penanggungjawab program, namun kadangkadang pengerjaan podcast menumpuk pada satu orang, yaitu produser. Hal itu biasanya terjadi karena kendala teknis dan nonteknis. Di saat penanggungjawab program lain tidak bisa siaran, maka produser mengambil alih peran sebagai presenter.

\section{Pangsa Pendengar Podcast Detik.com}

Seperti telah disinggung sebelumnya, Detik.com mulai meluncurkan podcast pada Februari 2020 dengan target untuk mendekati kalangan pembaca muda. Hingga sejauh ini pengguna yang mengakses program-program podcast Detik.com memang rata-rata berusia muda, terutama untuk konten podcast hiburan seperti Ngedrakordan Mainstage. Pendengar kedua program itu berada di kisaran usia 1827 tahun dan mayoritas berjenis kelamin perempuan. Namun, konten-konten ekonomi dan teknologi informasi juga cukup mendapat perhatian dari para pendengar muda, khususnya yang berjenis kelamin laki-laki.

Dengan demikian, baik Nugraha Rodiana maupun Angga Aliya ZR Firdaus memandang bahwa podcast telah berhasil menyasar khalayak baru untuk Detik.com, yaitu generasi muda. Capaian tersebut membuat mereka merasa yakin terhadap prospek yang ditawarkan podcast bagi media online untuk waktu-waktu mendatang. Karena itu, podcast Detik.com akan berusaha dikembangan lebih pesat lagi. Pengembangan tersebut dilakukan dari sisi penambahan sarana dan prasarana, peningkatan skill siaran awak redaksi, variasi program dan tema, serta penyempurnaan sistem delivery content.

Selain itu, podcast Detik.com juga mendapatkan tanggapan cukup positif dari para pendengar. Respons tersebut diketahui dari unggahan pendengar di akun media sosial maupun yang disampaikan langsung kepada awak redaksi. Menurut Atmi Ahsani Yusron, 
para pembaca umumnya menilai podcast makin melengkapi informasi yang telah didapatkan mereka dari berita-berita di laman detikHot. Beberapa pendengar juga menjadikan podcast detikHot sebagai tempat untuk mencari referensi sebelum melihat tayangan hiburan tertentu.

Namun, yang tidak kalah penting adalah pembaca mendapat pengalaman baru dalam mengakses konten berita detikHot. Apabila sebelumnya mereka hanya membaca berita dalam bentuk teks, kini mereka dapat mengakses berita dalam bentuk audio. Seperti beberapa tanggapan yang diterima redaksi, para pembaca umumnya mendengar podcast di jam-jam pulang kerja atau sambil menikmati waktu santai di akhir pekan. Mereka juga mengakses podcast untuk menyiasati ketertinggalan berita di detikHot dan Detik.com secara umum yang muncul silih berganti dalam waktu cepat.

Perilaku pengguna yang mengakses konten apa saja dan melalui apa saja ini merupakan tipikal dari konvergensi media. Selain itu sifat fleksibel (on demand) yang menjadi alasan utama pengguna menyukai podcast dari beberapa temuan sebelumnya juga tercermin dari tanggapan pendengar yang masuk ke redaksi Detik.com. Pertumbuhan dan karakteristik perilaku pengguna podcast yang unik telah menarik perhatian pengiklan. Beberapa perusahaan telah menjajaki kemungkinan untuk bekerjasama iklan di podcast Detik.com. Hal tersebut telah disimpulkan oleh redaksi Detik.com bahwasanya podcast mempunyai potensi besar untuk mendatangkan keuntungan bagi perusahaan.

\section{PENUTUP}

Podcast Detik.com diterbitkan untuk menjawab kebutuhan terhadap konten yang lebih variatif daripada sekadar berita teks. Peluncuran podcast Detik.com juga didorong oleh kebutuhan untuk meningkatkan jumlah pembaca muda, sekaligus untuk menjalin engagement (keterlibatan) yang kuat sejak dini dengan mereka melalui sarana teknologi baru tersebut. Pembaca muda diketahui menyukai konten berbentuk video dan audio. Podcast ditujukan untuk menciptakan pengalaman baru bagi jurnalis Detik.com dalam bercerita (storytelling) serta bagi pembaca dalam mengakses berita. Podcast dipilih karena memiliki banyak keunggulan dibandingkan dengan radio. Di antaranya podcast bersifat yang timeless, fleksibel atau dapat didengarkan kapan dan di mana saja, serta tidak dibatasi oleh durasi waktu.

Selain munculnya konten dan medium yang bervariasi, konvergensi media juga membuat perubahan pada praktek editorial di media massa. Hal tersebut juga terlihat pada proses pengerjaan podcast di Detik.com. Sebagian besar staf redaksi yang tidak mempunyai background dalam dunia broadcasting diterjunkan untuk menggarap podcast. Di sisi lain, mereka juga masih harus mengerjakan tugas-tugas peliputan dan penulisan berita setiap harinya. Alhasil, podcast menuntut para jurnalis di Detik.com untuk menguasai berbagai skill dan pekerjaan. Namun, hal itu bisa diatasi seiring dengan perjalanan waktu. Pembuatan podcast juga dilakukan dengan sederhana, cepat, dan tanpa mengeluarkan biaya yang mahal.

Jumlah pendengar podcast Detik.com sejauh ini belum begitu besar, namun terus meningkat dari waktu ke waktu. Konten podcast hiburan paling banyak diakses oleh pendengar dibandingkan konten lainnya. Pengungjung situs Detik.com memperoleh pengalaman baru dalam mengkonsumsi berita melalui podcast. Beberapa pengiklan juga mulai melirik podcast Detik.com, yang mengindikasikan bahwa podcast mempunyai prospek bisnis yang cukup menjanjikan. Penelitian tentang podcast dan media massa dengan teori dan penerbit berita yang berbeda sangat disarankan di waktu mendatang. Hal itu untuk mendapatkan gambaran lebih dalam tentang bagaimana tren teknologi digital podcast diadopsi oleh media massa di Indonesia untuk menunjang eksistensinya. 


\section{DAFTAR PUSTAKA}

Albarran, A. B. (2013). Media management and economics research in a transmedia environment. Routledge

Alten, R. S. (2014). Audio in Media (10th ed.). Wadsmorth.

Berry, R. (2016a). Part of the establishment: Reflecting on 10 years of podcasting as an audio medium. Convergence, 22(6), 661-671.

Berry, R. (2016b). Podcasting: Considering the evolution of the medium and its association with the word 'radio.' Radio Journal: International Studies in Broadcast \& Audio Media, 14(1), 7-22.

Burns, T. M. (2007). The forecast for podcasts: sunny skies but not necessarily with clear visibility. Neurology, 68(15), E19-E20.

Creswell, J. W. (2009). Research Design, Qualitative, Quantitative, And Mixed Methods Approach (Third). Sage Publications Sage CA: Los Angeles, CA.

DailySocial \& JakPat. (2018). Survei Penggunaan Layanan Podcast 2018.

Detikcom. (2020). Podcast Report(FebruaryMay).

Dwyer, T. (2010). Media convergence. McGraw-Hill Education (UK).

Edison Research. (2019). The Podcast Consumer 2019, A Report From The Infinite Dial.

Fidler, R. F. (1997). Mediamorphosis: Understanding new media. Pine Forge Press.

García Avilés, J. A., Meier, K., Kaltenbrunner, A., Carvajal, M., \& Kraus, D. (2009). Newsroom integration in Austria, Spain and Germany: Models of media convergence. Journalism Practice, 3(3), 285-303.

Geoghegan, M. W., \& Klass, D. (2008). Podcast solutions: The complete guide to audio and video podcasting. Apress.

Grant, August. E, \& Meadows, H. J. (2018). Communication Technology Update (16th ed.). Routledge.

Jenkins, H. (2006). Convergence Culture, Where Old Media dan New Media Collide. New York University Press.

Kumparan. (2019). Spotify Dorong Geliat Podcast di Indonesia. https://kumparan.com/millennial/s po tify-dorong-ge liat-podcast-diindonesia-1ssTHyZWSIr

Llinares, D., Fox, N., \& Berry, R. (2018). Podcasting: New aural cultures and digital media. Springer.

Lugmayr, Artur \& Zotto, C. D. (2016). Media Convergence Handbook-Vol. 1. Journalism, Broadcasting, and Social Media Aspects of Convergence. Springer.

McHugh, S. (2014). Audio storytelling: Unlocking the power of audio to inform, empower and connect. Asia Pacific Media Educator, 24(2), 141156.

Moleong, L. J. (2019). Metode penelitian kualitatif (Edisi Revisi). Rosda.

Neuman, W. L. (2014). Social Research Methods: Qualitative and Quantitative Approach

Newman, N. (2020). Journalism, media and technology trends and predictions 2020.

Quinn, S. (2005). Convergence's fundamental 
70 | Jurnal Komunikasi, Vol. 15 No. 01, Maret 2021: 55-70

question. Journalism Studies, 6(1), 29-38.

Reuters. (2019). News Podcasts and the Opportunities for Publishers. Digital News Project.

Reuters Institute. (2019). How Young People Consume News and the Implications for Mainstream. https://reutersinstitute.politics.ox.ac. uk/our-research/how-young-peopleconsume-news-and-implicationsmainstream-media

Tapsell, R. (2015). Platform convergence in Indonesia: Challenges and opportunities for media freedom. Convergence, 21(2), 182-197. 